\title{
MATRIZES TEÓRICAS DAS RELAÇÕES ÉTNICO-RACIAIS BRASILEIRAS
}

\author{
THEORETICAL MATRICES OF BRAZILIAN \\ ETHNIC RACIAL RELATIONS
}

\author{
Fabrizzia Christiane dos Santos ${ }^{1}$ \\ [https://orcid.org/0000-0002-9608-0046] \\ Sérgio Pereira dos Santos ${ }^{2}$ \\ [https://orcid.org/0000-0002-9608-0046] \\ DOI: 10.30612/raido.v15i37.14589
}

RESUMO: Este texto é parte da pesquisa de Mestrado em Educaçâo, vinculada ao Programa de Pós-Graduaçấo em Educaçăo (PPGE) da Universidade Federal de Mato Grosso (UFMT), junto à Linha de Pesquisa Movimentos Sociais, Política e Educaçâo Popular e ao Núcleo de Estudos e Pesquisas sobre Relaçōes Raciais e Educaçăo (NEPRE). Tem-se como objetivo apresentar as principais matrizes teóricas para compreensāo das relaçóes étnico-raciais no Brasil, sendo estas a Matriz Culturalista em Freyre (1977), a escola de Chicago, tendo como um dos expoentes Pierson (1971), a escola de Sociologia Paulista com Fernandes (2007), os novos estudos sobre as relaçōes étnico-raciais por Hasenbalg (2005) e reflexôes apresentadas por Paixăo (2014). Tais discussôes teóricas trazem possibilidades interpretativas para se pensar, a partir da noçấo de raça, como a sociedade brasileira construiu e ainda mantém, vantagens e desvantagens raciais entre pessoas negras e brancas. Para este levantamento utilizamos a pesquisa bibliográfica.

Palavras-chave: Raça; Relaçóes étnico-raciais; Racismo.

ABSTRACT: This text is part of the Master Degree's in Education linked to the Graduate Program in Education (PPGE) at the Federal University of Mato Grosso (UFMT), along with the Social Movements, Politics and Popular Education Research Line and to the Center for Studies and Research on Race Relations and Education (NEPRE). This text aims to present the main theoretical matrices for understanding ethnic-racial relations in Brazil, wich are the Matrix Culture-List in Freyre (1977), the Chicago School, that has Pierson (1971) as one of its exponents, the School of Sociologia Paulista by Fernandes (2007), our new studies on ethnic-racial relations by Hasenbalg (2005) and presented reflections by Paixâo (2014). Such theoretical discussions evoke

1 Programa de Pós-Graduaçăo em Educaçăo da Universidade Federal de Mato Grosso (PPGE - UFMT). Cuiabá. Mestra em Educaçấo. Professora Unidocente na Secretária Estadual de Educaçăo do Mato Grosso (SEDUC - MT).Email: fabrizzia_santos@hotmai.com.

2 Programa de Pós-Graduaçâo em Educaçăo da Universidade Federal de Mato Grosso (PPGE-UFMT). Cuiabá. Doutor em Educaçăo pelo Programa de Pós-Graduaçăo em Educaçăo da Universidade Federal do Espírito Santo (PPGE-UFES). Professor do Departamento de Teoria e Fundamentos da Educaçăo (DTFEUFMT).E-mail: santosdialogos@gmail.com. 
interpretive possibilities to think, via race notion, of how Brazilian society built and still maintains, racial advantages and disadvantages between black and white people. For this survey we used bibliographic research.

KEYWORDS: Race; Ethnic Racial Relations; Racism.

\section{INTRODUÇÃO}

Este artigo é base teórica para nossa pesquisa de mestrado em andamento, que busca compreender as relaçóes étnico-raciais entre jovens negras/os e brancas/os no contexto da escola pública, localizada no Mato Grosso. Para isso primeiramente fizemos uma pesquisa bibliográfica para levantamento teórico-metodológico que permita analisar as relaçōes étnico-raciais no Brasil.

Para tanto faz-se necessário entender uma categoria importante para nossa pesquisa enquanto instrumento de análise: o conceito de raça; bem como pensar como os pensamentos/práticas racialistas foram construídos e consolidados na sociedade brasileira, apresentando também as contrapartidas e disputas no campo teórico e político.

O presente texto traz as contribuiçōes teóricas para interpretar as relaçôes étnico-raciais no Brasil, a começar pela presença das terias raciais do final do século XVIII e início do século XIX; como foi visibilizada a ideia de "democracia racial" a partir de Gilberto Freyre e Donald Pierson, além das contribuiçôes da Escola de Chicago; em contraponto à harmonia racial defendida anteriormente, Florestan Fernandes desenvolve em suas pesquisas a crítica do mito da democracia racial; e em sua linha analítica Carlos Hasenbalg mantém a desmistificaçâo desse mito, acrescentando dados quantitativos que evidenciam a materialidade e a imaterialidade das desigualdades raciais. Toda essa reflexăo teórica permite também observar os diferentes tipos de levantamentos e de estudos realizados e como as pessoas negras foram, na maior parte das pesquisas, objeto (RAMOS, 1957). Sendo uma das principais características dos ditos novos estudos da relaçôes étnico-raciais sâo as que trazem a presença do colonizador branco como parte dessas relaçóes, questionando o papel da branquitude na (re) produçáo das relaçôes e discriminaçôes raciais.

\section{CONCEITO SOCIOLÓGICO DE RAÇA: QUEM É NEGRA/O E QUEM É BRANCA/O?}

Raça é um termo que remete a diferentes noçōes de mundo e de ciência e que após a $2^{\mathrm{a}}$ Guerra Mundial caiu em descrédito pelo que poderia despertar de valores racistas e eugenistas. Porém, a ideia de raça que nos subsidia é aquela desenvolvida, como já apontamos, por Guimarâes (2003) como um conceito sociológico que permite compreender como se classificam os grupos raciais nas relaçôes étnico-raciais brasileiras. Assim, de acordo com Guimaráes (2003, p. 104):

Se pensarmos em "raça" como uma categoria que expressa um modo de classificaçâo baseado na ideia de raça, podemos afirmar que estamos tratando de um conceito sociológico, certamente náo realista, no sentido ontológico, pois năo reflete algo existente no mundo real, mas um conceito analítico nominalista, no sentido de que se refere a algo que orienta e ordena o discurso sobre a vida social. 
Esse conceito se mostra uma categoria de análise básica para a interpretaçăo das relaçôes étnico-raciais entre jovens negras/os e brancas/os por permitir, enquanto instrumento conceitual, entender como uma ideia pode influenciar a construçâo de um imaginário que, por sua vez, se torna real na prática e na açăo dos sujeitos que crêem nela, os quais colocam este conceito em movimento quando se relacionam com outras pessoas estabelecendo distinçóes baseadas na classificaçăo racial.

No nosso caso, utilizaremos essa categoria para basear as reflexōes que faremos sobre as relaçôes étnico-raciais entre negras/os e brancas/os, o qual se constrói como discurso simbólico, e que ao mesmo tempo é produtor de realidades e fenômenos sociais, como a ideia de superioridade de um grupo sobre outro, provocando distinçôes de tratamento de pessoas ou a definiçăo de lugar racial-social, como no caso do racismo.

Veremos em Hofbauer (2006) que negro nem sempre significou algo ruim ou negativo, mas que a partir das grandes navegaçôes e o contato com diferentes povos, principalmente com negros africanos, o branco europeu elaborou justificativas variadas para sua posiçăo acima do negro e da sua cultura, de maneira que os negros foram inferiorizados, essencializados e invisibilizados na construçâo das sociedades ocidentais e no Brasil. Desse modo, a noçâo de alteridade nos permite compreender que a ideia de negro (e as tentativas de sua inferiorizaçâo) só surge em relaçâo ao outro com quem se compara e avalia, no caso o branco, sendo um processo de produçáo e desenvolvimento das relaçôes entre raças, por isso a constituiçâo social de relaçôes étnico-raciais.

Nesse sentido, considerando a materialidade da efetivaçăo da categoria raça nas relaçóes étnico-raciais, Nogueira (1985) nos ajuda a compreender quem é negro no Brasil a partir da sua elaboraçấo clássica sobre preconceito racial de marca e preconceito racial de origem. Para o autor, o preconceito racial de marca levaria em consideraçăo as características fenotípicas do sujeito, sua cor de pele, cabelo, nariz e boca que carregariam os sinais da inferioridade, como preguiça, incivilidade e feiura de um, marcado pela cor da pele escura, enquanto o outro grupo seria a marca da civilizaçăo, da beleza, da inteligência, no caso a/o branca/o. Sem desconsiderar que tais significados negativos e positivos sâo produzidos social e historicamente nas relaçôes étnico-raciais brasileiras, continua o autor, que o preconceito racial de origem estaria mais relacionado à ascendência, ou seja, ao sangue e a fatores genéticos. Esta conceituaçăo nos permite pensar que no Brasil negro é aquele visto socialmente como originado e marcado pelo que de pior existiria em termos de compreensáo de uma pessoa remontando a pele negra a descendência de escravos, a concepçóes de algo infeccioso, chulo ou a extremamente depreciativo e estigmatizantes.

A definiçâo de Nogueira (1985) nos leva a pensar o/a negro/a e o/a branco/a a partir de uma relaçăo entre quem está no topo de uma relaçâo hierarquizada e quem está embaixo, acrescentamos a essa noçâo relacional uma outra que podemos chamar de situacional, ou seja, a definiçấo de branco e negro também depende da situaçâo e da posiçấo em que os sujeitos ocupam nessas relaçóes, conforme Hasenbalg (2005).

As formulaçōes de Nogueira (1985) nos ajudarăo a refletir sobre as relaçôes étnico-raciais em suas dinâmicas e elaboraçâo de posiçôes hierárquicas ou nâo, pois os fundamentos das classificaçōes étnico-raciais no Brasil foram, e ainda săo marcados 
por características fenotípicas, de origem e comportamentais que alocam sujeitos hierarquicamente, para receber seus privilégios e suas desvantagens, materiais, simbólicas e psicológicas.

Outro autor que pode subsidiar nossas reflexóes sobre as identidades étnico-raciais é Gilberto Freyre (1977), um dos responsáveis por uma interpretaçăo que pode gerar confusăo nas leituras apressadas, sobre quem seria branco e negro no Brasil, por exemplo. Ele desenvolveu a ideia de relaçóes harmoniosas entre brancos e negros, e acrescentou o mestiço para se referir aqueles que seriam misturados, nem branco nem negro, e que hoje no Brasil fazem parte das dinâmicas das relaçōes étnico-raciais. Mas mais uma vez podemos destacar que essa confusâo năo se faz tăo presente para definir brancos e negros quando pensamos quais săo as pessoas e as características de quem carrega as marcas da beleza, da inteligência e da civilizaçăo de um lado e das qualidades negativas do outro.

\section{DO RACISMO CIENTÍFICO ÀS REFORMULAÇÕES SOBRE RELAÇÕES ÉTNICO-RACIAIS NO BRASIL}

O conjunto de ideias e crenças sobre determinadas situaçóes, sociedades ou pessoas năo é algo que acontece espontaneamente nem de modo harmônico, săo processos sociais, culturais, econômicos que se retroalimentam na construçâo das sociedades e dos grupos humanos. Dessa maneira, a ciência pode ser entendida, entăo, como uma instituiçấo que se nasce de um processo, em primeiro lugar de rompimento com uma visăo/explicaçăo de mundo religiosa, mas que nâo deixou de lado alguns dos pressupostos ligados à religiâo, como a hierarquia entre seres humanos.

Assim, foi a partir do final do chamado "Século da Luzes", que a ciência ganha destaque, pois aos poucos vai erigindo o homem branco europeu como modelo de humanidade e de civilizaçăo, legitimando por meio de estudos científicos da Antropologia Física, da Medicina Legal e do Direito por exemplo, que passou a utilizar métodos de observaçăo, de mediçấo, de testagem e de comprovaçăo como forma de legitimaçăo do conhecimento produzido, considerado objetivo e verdadeiro enquanto explicaçáo das diferenças entre as raças (SCHWARCZ, 1993).

O contato com diferentes povos já existia desde muito antes das grandes navegaçôes promovidas pelos europeus da Península Ibérica, sendo que os africanos migraram para diferentes regióes do planeta e as suas características físicas nem sempre foram motivo de inferiorizaçáo, como trouxe Hofbauer (2006), e quando o foram assim classificados ainda năo carregava a sistematizaçăo e legitimidade da explicaçăo científica. De acordo com Schwarcz (1993, p. 64-65):

[...] é apenas no século XIX, com as teorias das raças que a apreensăo das "diferenças" transforma-se em projeto teórico de pretensăo universal e globalizante. "Naturalizar as diferenças" significou, nesse momento, o estabelecimento de correlaçôes rígidas entre características físicas e atributos morais. Em meio a esse projeto grandioso, que pretendia retirar a diversidade humana do reino incerto da cultura para localizá-la na moradia segura da ciência determinista do século XIX, pouco sobrava para o arbítrio do indivíduo. Da biologia surgiram os grandes modelos e a partir das leis da natureza é que se classificavam as diversidades. 
Nesse período, as teorias racialistas partiam da naturalizaçăo das características humanas, sendo irrevogáveis e só poderiam ser controladas ou eliminadas pela ciência, de modo que nas diversas áreas se pensava em justificar as hierarquias, bem como as estratégias para lidar com elas, inclusive por meio da força.

De acordo com Bethencourt (2018), o racismo científico foi uma corrente que se iniciou no século XIX e atuou no sentido de construir uma visăo sobre a/o negra/o e a sua cultura, nem sempre com vistas à sua valorizaçăo, pelo contrário, muitas vezes sendo utilizado para legitimar e consolidar velhos preconceitos e estereótipos raciais.

Esse trabalho da ciência é realizado tanto na Europa quanto nos Estados Unidos, e uma das formas de explicaçăo das diferenças parte da origem do ser humano que alguns cientistas tratavam como monogênica e outros como poligênica. Este debate, apesar de trazer diferentes origens chegava sempre num ponto comum, a inferioridade do negro. Assim, na visăo monogênica os negros seriam os descendentes de Cam, erráticos, ou ainda de cultura e comportamentos inferiores, nâo chegariam ao ponto máximo da civilizaçăo branca; no caso da visâo poligênica traz na origem uma diferença enquanto desigualdade que se perpetua, sendo as raças mais adaptáveis aquelas que sobrevivem e dominam os incapazes (BETHENCOURT, 2018).

Diante das explanaçôes de Bethencourt (2018) e Schwarcz (1993) percebemos como a Teoria da Evoluçấo de Darwin foi utilizada nas explicaçôes de fenômenos humanos, dando margem para as discussóes sobre o darwinismo social, por exemplo, como argumento na defesa de modelos políticos para a colonizaçáo e subalternizaçâo simbólica e material de povos africanos e seus descendentes, pois estes seriam incapazes de se desenvolver sem a orientaçâo e controle do homem branco europeu racional, sendo a escravidâo, por exemplo, vista como uma forma de benevolência do branco na educaçấo do negro para o trabalho e vida em sociedade.

Assim, a partir das pesquisas de Schwarcz (1993) podemos destacar em linhas gerais que o monogenismo agregou a maior parte dos cientistas iluministas, como J.J. Rousseau, e muitos que através da Bíblia explicavam uma origem única/una da humanidade, as desigualdades dos grupos seriam resultado da degeneraçăo; desta forma poder-se-ia dizer que haviam graus de humanos, mais ou menos próximos da perfeiçâo, aceito numa linha de raciocínio evolutiva. Assim, continua Schwarcz (1993) que o poligenismo contestava os pressupostos acima ao descrever várias origens desiguais para os grupos humanos, numa crescente utilizaçăo de argumentos biologizantes corroborados pelos estudos quantitativos das medidas de crânios, cérebros e corpos. Essa vertente essencializa os sujeitos determinados por sua herança genética, tendo Cesare Lombroso ${ }^{3}$ como um de seus representantes, que associava características físicas a comportamentos em seus estudos sobre o perfil dos criminosos, influenciando diversas áreas como a Psicologia, as Artes, o Direito, a Antropologia, para as quais as diferenças seriam entăo a prova da existência de tipos e espécies distintas.

3 Costa(2006) retoma Lombroso (1836-1909) em seus estudos e destaca como esse médico italiano defendia a eliminaçâo das pessoas negras por as considerarem tal raça degenerada, propensa naturalmente à criminalidade, um risco que deveria ser contido para nâo passar às geraçôes futuras, apresentando a ideia de 'seleçăo benéfica' para fortalecer e completar a seleçăo natural. 
Nesse sentido, podemos retomar as discussóes sobre as medidas dos crânios e dos corpos que eram consideradas provas das aptidóes para o trabalho braçal, no caso das pessoas negras e aptidóes para o desenvolvimento cognitivo dos brancos, o que servia para explicar também as relaçōes desiguais e violentas dos trabalhos forçados e de baixa remuneraçấo de negras/os, sua inaptidâo para a educaçáo e as ciências devido ao seu baixo Quociente de Inteligência (QI), tendo ainda hoje sendo utilizados os "famosos" testes de QI.

Na Europa, as teorias raciais tiveram como expoentes, dentre eles, na França Georges Cuvier, Arthur de Gobineau, na suíça Louis Agassiz e na Inglaterra Robert Knox, entre outros. Para Schwarcz (1993) os ideais racistas foram difundidos no Brasil por meio da adaptaçăo dessas teorias às questôes específicas de nosso país, como foi o caso do debate sobre a miscigenaçăo. Desse modo, a dimensăo dessa ciência no Brasil pode ser percebida a partir das filiaçôes aos ideários importados e as instituiçóes em que se desenvolveram por aqui, abordando de diversas maneiras os estudos sobre raça.

Nessa direçấo, trazer a relevância do papel das instituiçóes no debate racial, na sua defesa e na sua crítica é uma das preocupaçôes de Schwarcz (1993, p. 66), pois "nos museus etnológicos, institutos históricos, escolas de direito e medicina, a discussâo racial assumiu um papel central, sendo rica a análise de tais estabelecimentos, de onde partiram respostas alternativas apesar de contemporâneas".

\section{TEORIA DA MESTIÇAGEM E A POLÍTICA DE ESTADO DE BRANQUEAMENTO NO BRASIL}

Tais concepçóes eurocêntricas e eugênicas tiveram como expoente brasileiro, o médico maranhense Raimundo Nina Rodrigues, que justificava a inferioridade do negro defendendo o discurso da raça biológica. Para ele, o branco era a raça superior e o negro a inferior. Ele tentou provar isso através de mediçōes físicas, e mesmo sem ser favorável a mestiçagem, porque segundo ele, ela degeneraria a raça. E há que se considerar também que as suas ideias influenciaram, de alguma forma, uma interpretaçâo das relaçóes étnico-raciais que reforçavam a ideia de que o branco e suas características físicas e morais era o modelo para o brasileiro.

Há que se considerar que Nina Rodrigues é pioneiro nos estudos da cultura afro-brasileira, suas danças, religióes e línguas por meio de um olhar biologizante e hierárquico conforme premissas deterministas. Assim, como aponta Leite (2007), o médico é pessimista na possibilidade de civilizaçăo de negros, apesar de considerar que vieram negros mais adiantados da regiâo do Egito, em que esses seriam brancos disfarçados.

Em resumo, Nina Rodrigues aceitava integralmente o evolucionismo do século XIX e considerava que, entre os outros países, o Brasil se inferiorizava, năo só pela existência de negros, mas também pela mestiçagem. Se os Estados Unidos conseguiram progredir, isso se devia ao fato de terem estabelecido uma separaçăo nítida entre brancos, de um lado, mestiços e negros, de outro; além disso, o clima temperado favoreceria os brancos na luta pela vida, enquanto os trópicos favoreceriam os negros e mestiços (LEITE, 2007, p. 289-290). 
O determinismo biológico e geográfico de Nina Rodrigues possivelmente ensinados até hoje nas escolas de Medicina ${ }^{4}$, reproduzidas e disseminadas em instituiçóes legitimadas como espaços de saber săo, entre outros fatores, aqueles que contribuem para a sistematizaçăo de preconceitos e formas de discriminaçăo racial contra pessoas negras. Assim, revisitar tais pressupostos nos ajudam a entender as origens e os caminhos de construçăo de um imaginário social assentado na ideia de raças superiores e inferiores, que vai de alguma maneira refletir nos processos legitimadores de identidades negras e brancas nos espaços sociais, como a escola. Portanto, săo ideias que vâo marcar tomadas de decisóes e políticas públicas, dentre elas as chamadas políticas de branqueamento como forma de diminuir e até eliminar o "problema negro" e a própria populaçâo negra, seja por embranquecer suas contribuiçôes culturais, consideradas patrimônio nacional, seja também pelas formas de eliminaçăo física do fator negro, como veremos em Domingues (2004) e em Skidmore (1976).

Skidmore (1976) e Domingues (2004) mostram como o governo brasileiro deliberadamente utilizou estratégias de eliminaçâo do negro os enviando para a frente de batalha na Guerra do Paraguai, já contando com um número de mortes em batalha, e prometendo alforria após a batalha, o que nâo ocorreu, pois muitos năo sobreviveram. Os autores ainda apontam que o negro também foi eliminado das decisóes e preocupaçóes no pós-aboliçăo realizada dentro da burocracia da lei, ou seja, sem considerar a participaçăo da populaçâo negra, tentando eliminar as suas contribuiçôes enquanto sujeitos históricos, desconsiderando suas demandas, como a necessidade da reforma agrária.

Há dados que nos permitem questionar a tentativa de construçâo de uma imagem da populaçăo negra enquanto povo incapaz de organizaçáo e que por isso deveria permanecer controlada e tutelada. Assim, a aboliçâo ocorreu sem a reforma agrária como previa alguns setores do movimento abolicionista, como um dos esforços públicos de nâo reconhecimento das demandas e atuaçăo da populaçăo negra, o que pode ser considerada uma forma de branquear a história, feita somente por "homens civilizados" (SKIDMORE, 1976).

Domingues (2004) também trabalha para evidenciar como o governo brasileiro atuou para impedir o acesso de negros à cargos honoríficos, como a igreja restringia a participaçáo do negro em papéis de relevância, já que nas escolas negros podiam trabalhar, mas năo estudar, havia ainda a proibiçăo de bailes de negros, proibiçăo do voto e substituiçấo de mâo-de-obra com o incentivo a vinda de imigrantes europeus através

4 A pesquisa de Jurema Werneck (2005) traz dados que permitem visualizar a materializaçăo das desigualdades raciais presentes no sistema público de saúde e possivelmente resultados de uma formaçăo profissional e de políticas públicas racializadas institucionalmente que mantém uma visăo estereotipada e determinista das pessoas negras. Os dados por ela levantados apontam para o fato de que, se houve um decréscimo total de mortes infantis, por outro lado o número de mortes de pessoas negras menores de 1 ano passou de 21 para 40\%, praticamente dobrando dos anos 1980 aos 2000; a taxa de mortalidade de mulheres negras é 2,9 vezes maior que a de brancas, em se tratando de causas evitáveis por meio do pré-natal e assistência adequada no parto. Podemos questionar que entre 1993 e 1998 a morte materna foi de 7,4 vezes maior para negras; a taxa de mortalidade por Aids é praticamente o dobro em pessoas negras, sendo que em grande medida sâo mortes evitáveis por meio de um acompanhamento, prevençâo e tratamento adequados. Assim, podemos pensar que a formaçăo dos profissionais de saúde ainda possa estar enviesada por uma visâo distorcida e estereotipada das pessoas negras, consideradas racialmente mais resistentes fisicamente a dor, sujeitas por isso a um menor cuidado e até negligência médica/hospitalar. 
de políticas públicas como a concessăo de terras devolutas e adaptaçăo de teorias racializadas revendo o papel da mestiçagem como forma de desenegrecer o Brasil. Nas palavras do autor destacamos:

[...] ao contrário do que se difunde no Brasil, a discriminaçáo racial contra o negro esteve cravada na legislaçăo da Colônia e do Império, tornando-se, em larga escala, um traço da tradiçáo cultural do país. Na época da escravidăo, leis de diversas naturezas privavam o negro livre ou forro de usufruir dos mesmos direitos concedidos aos brancos. Em alguns casos, os negros ficavam apartados dos brancos, năo podendo assumir cargos na administraçâo pública, nem seguir carreira religiosa e militar. A discriminaçăo racial também atingia o negro no embrionário mercado de trabalho livre. No século XIX, por exemplo, as regulamentaçóes para locaçáo de serviços no campo mantinham cláusulas discriminatórias. Além disso, todos os programas de ocupaçăo dos núcleos coloniais traziam dispositivos que vetavam direta ou indiretamente a presença do negro (DOMINGUES, 2004, p. 78).

O processo de branqueamento pode nos ajudar a entender como historicamente foram criadas estratégias para impedir a "entrada" de pessoas negras em alguns lugares ao mesmo tempo em que facilitava ou privilegiava a populaçáo branca que nada tinha de superior, senáo náo careceria de facilitaçôes para sua posiçáo. Retomamos Domingues que explica parte desse processo de branqueamento:

Mostramos, também, como na segunda metade do século XIX, o negro, na posiçăo
de principal agente produtivo do país, era repelido como opçăo de máo-de-obra na
transiçáo do trabalho escravo para o trabalho livre. As teorias racionalizadoras da
exclusáodonegrodomercadodetrabalhoagrícola eramjustificadasideologicamente
por dois eixos centrais. Primeiramente, pelo racismo científico. Baseado na
superioridade biológica, cultural, intelectual e moral do branco, propagava-se um
discurso de desqualificaçáo do negro. Na obra dos intelectuais da época, inclusive
na dos estrangeiros, o negro e/ou africano era, invariavelmente, representado
pejorativamente e considerado imprestável para suprir a suposta escassez de
máo-de-obra. Em segundo lugar, a exclusáo do negro era justificada pelo discurso
do branqueamento, que, por sua vez, fundamentava o programa imigrantista de
substituiçấo do trabalhador africano (ou afro-brasileiro) pelo europeu, do negro
pelo branco. A escolha do imigrante europeu tinha a intençăo de depuraçăo da "raça"
(DOMINGUES, 2004, p.78-79).

Para Skidmore (1976), o branqueamento no Brasil era aceito e estimulado pela elite branca, principalmente entre os anos de 1889 e 1914, e este processo presumia a superioridade da populaçáo branca, onde os negros tenderiam ao desaparecimento através da miscigenaçâo que clarearia a populaçâo com a força do gene branco, além do fato dos sujeitos procurarem sempre parceiros mais claros para se relacionar sexualmente. Portanto, nessa hipótese ao fim de um século, ou pouco mais, já năo existiriam negros.

Conforme Domingues (2004) um dos expoentes dessa perspectiva de eliminaçâo dos negros foi cientista brasileiro Joăo Baptista de Lacerda (1846-1915), médico, antropólogo e diretor do Museu Nacional, que representou o Brasil no I Congresso Universal das Raças, no ano de 1911 em Londres, onde apresentou suas estatísticas prevendo que em 2011 a populaçăo negra seria de 0\%, mestiços 3\%, índios 17\% e 
brancos $80 \%$. Ele foi o único latino-americano nesse Congresso, e defendia que o tipo latino era mais preferível do que o alemáo para arianizar o Brasil por serem mais adaptáveis aos trópicos enquanto os alemăes seriam mais fechados em suas comunidades no sul do país. Ele defendeu que a desorganizaçăo dos negros seria outro motivo de sua própria extinçăo. Isso nos chama a atençăo que sendo o único latino-americano no Congresso, o autor foi bastante criativo na sua soluçăo do problema do negro, preferindo os latinos.

Esta perspectiva considerada otimista por quem defendia a eliminaçāo do problema negro, năo era partilhada entre todos, porque para Sílvio Romero esta limpeza poderia levar até 8 geraçôes para ser eliminada de vez, tanto em aspectos fenotípicos quanto genéticos. Nesse caso, para Romero os mestiços jamais desapareceriam a menos que em todas as miscigenaçóes houvesse sempre um parceiro muito claro senăo branco. Para essas conclusōes, Romero năo apresentou estatísticas, mas tendia sempre a duvidar de toda informaçâo e conhecimento que se tornassem estabelecidos. Nesse caso nos parece que a crítica pela crítica era seu método (SKIDMORE, 1976).

Sendo assim, a soluçăo brasileira por Romero para o "problema do negro" foi a busca pelo branqueamento, tanto físico quanto cultural, tendo na miscigenaçăo uma das saídas para a progressiva eliminaçăo do negro. Mas nem todos explicaram a miscigenaçăo da mesma forma. Freyre (1977), por exemplo, defendia a riqueza da identidade nacional por meio dessa característica de nosso país: ser miscigenado.

\section{MATRIZES CLÁSSICAS DAS RELAÇÕES ÉTNICO-RACIAIS NO BRASIL}

Năo existe somente uma forma de compreender as relaçôes étnico-raciais no Brasil e o recorte teórico que fizemos e embasamos, é, certamente, parte de tantas interpretaçôes que se tornaram clássicas pela repercussăo, também pela permanência de suas leituras, muitos no campo científico, mas várias já de certo modo, absorvidos pelo imaginário social (SEYFERTH, 1989), como é o caso de "leituras" biologizantes, culturalistas, aquelas que primam pela explicaçâo de classe, também abordagens que rompem com naturalizaçôes. Assim, mesmo que sejam perspectivas divergentes, e até por isso, merecem ser aprofundadas, também porque as contradiçóes, divergências, aproximaçôes entre as obras pesquisadas podem expressar justamente as permanências, mudanças e ressignificaçăo das ideias e práticas acerca das relaçóes étnico-raciais.

\subsection{Matriz Culturalista: Gilberto Freyre e as relaçōes raciais}

Como contraponto à visăo racialista, Gilberto Freyre (1977) se mostra um importante pesquisador no sentido de "desconstruir" as afirmaçóes com base em leituras biologizantes da humanidade e propóe que as diferenças sejam percebidas como resultado da cultura; no seu livro Casa-Grande e Senzala, escrito em 1933, o autor destaca as contribuiçōes das culturas indígena, africana e europeia na construçăo do povo brasileiro enquanto civilização.

Há que se considerar que Freyre năo rompe totalmente com o paradigma determinista, pois em várias análises considera as características comportamentais das pessoas negras como essências, coisificadas, como algo biológico, logo da dimensâo da 
natureza, como podemos ver no trecho: “Pode-se juntar, a essa superioridade técnica e da cultura dos negros, sua predisposiçăo como que biológica e psíquica para a vida nos trópicos. Sua maior fertilidade nas regiōes quentes" (FREYRE, 1977, p. 286). Em outras passagens do Livro Casa Grande \& senzala o autor relaciona aspectos físicos e morais, como a adaptabilidade quase inata dos negros ao trabalho escravo.

Gilberto Freyre enquanto discípulo de Franz Boas teve como influência a perspectiva culturalista. Assim, de acordo com Costa (2006), Hofbauer (2006) e Paixâo (2014) a preocupaçăo boasiana era descreditar as diferenças humanas com base biológica, por outro lado năo abria mâo do viés evolucionista do conceito de cultura para explicar tais diferenças. Assim, por mais que evitasse partir de uma pureza/ hierarquia racial, tinha como base um modelo de cultura/civilizaçăo a ser alcançado pela humanidade, logo construiu uma teoria etnocêntrica ao hierarquizar os sujeitos com base na cultura. Destacamos ainda que sua preocupaçăo em desconstruir a ideia de pureza racial vai influenciar Freyre acerca da mestiçagem enquanto uma realidade năo necessariamente negativa.

Ao explicar as relaçóes na Casa-Grande, Freyre discorre sobre a rotina da família patriarcal que envolve também os servos, principalmente aqueles que trabalham na casa, descrevendo minuciosamente as relaçôes entre senhor e escravo na cozinha, no quarto, na fazenda, na igreja, todos espaços da Casa-Grande, numa espécie de microcosmos, onde um dos principais indicativos de harmonia, segundo ele, é a relaçáo próxima, no mesmo espaço, envolta por afetos e portanto íntima e harmoniosa, apesar dos conflitos pontuais, que ele evidencia em várias passagens dessa obra. Prova dessa relaçáo foi a própria intimidade entre senhores e escravas, por exemplo, as quais serviam seus corpos aos senhores de bom grado.

A força, ou antes, a potencialidade da cultura brasileira parece-nos residir toda riqueza dos antagonismos equilibrados; o caso dos pronomes que sirva de exemplo. Seguirmos só o chamado 'uso português', considerando ilegítimo o 'uso brasileiro', seria absurdo. Seria sufocarmos, ou pelo menos abafarmos metade de nossa vida emotiva e das nossas necessidades sentimentais, e até de inteligência, que só encontram expressáo no 'me dê' e 'me diga'. Seria ficarmos com um lado morto; exprimindo só a metade de nós mesmos. Nâo que no brasileiro subsistam, como no anglo-americano, duas metades inimigas: a branca e a preta; o ex-senhor e o ex-escravo. De modo nenhum. Somos duas metades confraternizantes que se vêm mutuamente enriquecendo de valores e experiências diversas; quando nos completarmos num todo, nâo será com o sacrifício de um elemento ao outro (FREYRE, 1977, p. 335, grifos nossos).

É evidente que a obra de Freyre (1977) năo se resume a estas linhas, mas em suma ele considerava que as relaçóes entre brancos, negros e mestiços eram boas e como resultado tínhamos o brasileiro, mestiço, que teria as melhores qualidades da mistura de cada povo, como a inteligência e miscibilidade do português, a capacidade de adaptaçáo do negro ao trabalho escravo e a convivência de ambos em relaçóes afetivas, que segundo o autor era o potencial de equilibrar os conflitos e hierarquia por meio da intimidade.

Paixăo (2014) contribui com a análise da questăo acima ao trazer Freyre, o qual fez comparaçóes entre as relaçóes raciais nos Estados Unidos e no Brasil. Nos E.U.A., 
a separaçâo física entre pessoas negras e brancas era mais evidente, sem a intimidade sexual, por exemplo, aqui a colonizaçăo pelos portugueses teria sido táo flexível e tolerante a ponto de haver intercurso sexual com negras, promovendo uma relaçáo afetiva, prova da plasticidade e constituiçăo positiva da escravidăo no Brasil. Dessa forma, o resultado dessas relaçôes seriam os filhos miscigenados e sem condiçăo de diferenciaçấo por serem todos brasileiros, além disso, mesmo que houvesse uma relaçâo de hierarquia, os senhores paternalistas garantiriam alguma proteçăo social desses filhos, como alimento e cuidados na velhice.

Nâo obstante, apesar do autor dar ênfase às relaçôes harmoniosas, ele descreve cenas que nos permitem identificar situaçōes de conflito:

Năo săo dois nem três, porém muitos os casos de crueldade de senhoras de engenho contra escravos inermes. Sinhas-moças que mandavam arrancar os olhos de mucamas bonitas e trazê-los a presença do marido, à hora da sobremesa, dentro da compoteira de doce e boiando em sangue ainda fresco. Baronesas já de idade que por ciúme ou despeito mandavam vender mulatinhas de quinze anos a velhos libertinos. Outras que espatifavam a salto de botina dentadura de escravas; ou mandavam-lhes cortar os peitos, arrancar as unhas, queimar a cara ou as orelhas. Toda uma série de judiarias (FREYRE, 1977, p. 337).

Nesse sentido, mesmo que Freyre tenha sido aquele quem ajudou a divulgar a imagem de um Brasil como paraíso racial, ele năo deixou de escrever sobre detalhes das relaçôes entre brancos e negros que destacam sim a existência de conflitos, mesmo que para o autor năo fossem o mais relevante da sociedade escravista brasileira. Como também a trajetória de negros fora dos estereótipos raciais conforme Freyre (1977, p. 299) sobre seu letramento e a escrita: “É que nas senzalas da Bahia de 1835 havia talvez maior número de gente sabendo ler e escrever do que no alto das casasgrandes", bem como seu elevado conhecimento e especialidade na forja de metais, na criaçăo de gados e ótimos comerciantes, importantes tecnologias para o desenvolvimento do Brasil.

Sobre Freyre também podemos destacar que seus estudos ao mesmo tempo em que ajudaram a "descontruir" a ideia de inferioridade racial do negro, trouxe, por outro lado, uma visăo evolucionista, portanto hierárquica, do campo biológico para o campo cultural, ou seja, ele "trocou seis por meia dúzia". Segundo Leite (2007), Freyre tinha na imigraçáo do Ibérico o modelo a ser alcançado pelo brasileiro, ele via na mestiçagem, e na imigraçâo europeia, a chance de desenvolvimento do Brasil, porque a mestiçagem aqui poderia ser entendida também como um branqueamento cultural.

Freyre (1977) é fundamental para compreender as relaçôes étnico-raciais no Brasil de diferentes ângulos, dentre as principais que destaco agora săo: I- o "rompimento" com uma visâo biologizante das relaçôes étnico-raciais, como inaugurou Freyre, podem fazer crer que năo existem conflitos raciais; II- a noçăo de que a convivência no mesmo espaço e relaçōes próximas podem reforçar a ideia de harmonia e democracia racial, que nâo ignoram conflitos, mas que estes nâo seriam algo relevante; III- que a riqueza cultural da populaçấo negra e africana pode nâo ultrapassar uma visâo hierárquica das culturas africanas e europeias, mantendo crenças e posiçōes sociais baseadas na raça; IV- A miscigenaçâo é uma realidade que pode influenciar a percepçăo que pessoas negras e brancas têm de si e dos outros. Dessa forma, as ideias 
de Freyre certamente podem nos auxiliar em análises sobre as relaçōes étnico-raciais na escola, como a compressáo das dinâmicas e ambiguidades nas relaçôes entre jovens negras/os e brancas/os. Tentaremos por isso perceber em que medida algumas dessas ideias podem ou nấo estar naturalizadas pelos sujeitos ou que ainda possam trazer reflexōes e dissidências no contexto escolar.

\subsection{Donald Pierson e a Escola de Chicago}

Ainda assim essa interpretaçăo das relaçôes étnico-raciais no Brasil como amenas, atraiu a atençăo de estudiosos estrangeiros, brasilianistas, patrocinados pela Organizaçăo das Naçóes Unidas para a Educaçăo, a Ciência e a Cultura (UNESCO) ${ }^{5}$, que viam um modelo de sociedade a ser estudado, com características diferentes daquelas vistas entre negros e brancos nos Estados Unidos, África do Sul, na Índia e na Alemanha, por exemplo.

Um dos pesquisadores que participa do Projeto da Unesco no Brasil será Donald Pierson, com influência da Escola de Chicago. Ele foi um sociólogo estadunidense que a partir do final da década de 1930 desenvolve na Bahia e Săo Paulo, pesquisas sobre as características das relaçóes étnico-raciais entre brancos e negros comparando a realidade local com os Estados Unidos. Em seu primeiro estudo no Brasil acontece em Salvador, pois, segundo ele, essa cidade foi durante muitos séculos a porta de entrada de pessoas africanas escravizadas, sendo o momento de sua pesquisa pouco após a Aboliçâo, mais especificamente entre 1935 e 1937; essa proximidade com o fim da aboliçâo, junto ao baixo desenvolvimento e urbanizaçăo local teriam mantido a regiâo em condiçóes muito próximas daquelas que marcaram o contato entre grupos raciais distintos (PAIXÂO, 2014). O autor passou quase dois anos em sua pesquisa de campo e considerou, como Freyre, a miscigenaçáo um dos principais atenuantes das relaçóes entre pessoas negras e brancas. Desenvolve assim três categorias centrais, miscigenaçấo, classe e status para explicar essas relaçôes que diferentemente dos Estados Unidos permitia a ascensáo social ascendente de pessoas negras, sendo essa mobilidade, a prova da inexistência de barreiras raciais. Desse modo, para Pierson (1971), a mestiçagem era muito comum entre brancos e negros, através de casamentos inter-raciais, por exemplo, fator que eliminava a barreira da cor. E ainda desenvolve o pensamento de que:

Năo existiam na Bahia castas baseadas em raça; existem somente classes. Isto năo quer dizer que năo exista discriminaçăo em que estejam envolvidas pessoas de côr, mas sim que a discriminaçăo existente é de classe e năo de casta. É o tipo que existe entre os próprios homens de côr nos Estados Unidos, cuja intensidade é maior do que geralmente se pensa. $O$ fato de náo ter surgido na Bahia o sentimento de casta talvez seja devido a nunca ter o brasileiro branco se sentido ameaçado no seu status pelo prêto ou mestiço como grupos. As experiências passadas e presentes com a gente de

$5 \quad$ No Pós $2^{\mathrm{a}}$ Guerra Mundial, e diante dos seus efeitos devastadores para a humanidade, a UNESCO investirá em pesquisas no Brasil sobre as questôes raciais. Essa instituiçấo faz essa escolha devido a ideia de paraíso racial que se propagou mundialmente sobre o país, onde năo haveria grandes desigualdades raciais ou impedimentos para mobilidade social para a populaçáo negra. Sobre as pesquisas da Unesco ver Paixăo (2014), Pereira (2013) e Hofbauer (2006). 
côr năo foram de natureza a despertar nos brancos sentimentos de desconfiança, apreensấo, mêdo, pavor, ressentimento ou inveja, que fazem parte do preconceito de raça (PIERSON, 1971, p. 353).

Pierson (1971) destaca que, apesar de existirem diferenças fenotípicas como a cor da pele, cabelo e nariz; estas nâo seriam impedimentos para ascensâo social visto que muitos negros e mestiços ocupavam posiçôes de elevado status social; a ascensáo ou mobilidade social ascendente dependeria do esforço de cada sujeito (via meritocrática) por năo existir barreira de cor. O autor utiliza outra categoria para compreender as disparidades entre brancos e negros, que segundo ele seriam, portanto, de ordem social e nâo racial. Assim, ele explica a estratificaçâo social e a ascensâo social dos mestiços por meio do conceito de "sociedade multirracial de classes".

Assim, o que encontramos na Bahia é uma sociedade multirracial de classes. Năo existe casta baseada em raça; existem apenas classes. Estas classes estăo ainda consideravelmente identificadas com a côr, é verdade; mas apesar disto, săo classes e náo castas. A tendência mais característica da ordem social baiana tem sido a reduçâo gradual, mas contínua, de todas as distinçôes culturais e raciais, e para a fusăo biológica e cultural do africano e do europeu em uma raça e cultura comuns (PIERSON, 1971, p. 358).

Paixăo (2014) explica que para Pierson, a estratificaçăo seria social e teria quatro principais motivos: o primeiro, em decorrência do curto tempo após a aboliçáo teria como consequência o ingresso do negro no mundo do trabalho livre num patamar mais baixo tanto na escala educacional quanto na profissional; em segundo, o baixo desenvolvimento industrial e de urbanizaçấo de Salvador dos anos 1930 possibilitavam poucas oportunidades de emprego para a populaçâo em geral; em terceiro, o sistema educacional com poucas oportunidades e com preconceito social contra os pobres, seria um espaço desestimulantes às camadas mais baixas, das quais os negros faziam parte; e por último, o quarto motivo, o fato de năo haver conflito racial direto entre negros e brancos como nos Estados Unidos, impediu que se criasse uma consciência de grupo racial que motivasse a competiçấo por melhores condiçôes e status.

Podemos sistematizar as contribuiçóes de Pierson a partir da explanaçăo de Paixăo (2014, p. 109):

O rigor teórico da obra de Donald Pierson é evidente. Sua pesquisa de campo foi razoavelmente ampla, envolvendo múltiplos aspectos da vida social da cidade de Salvador e, de certo modo, de todo o Brasil. Deve ser salientado, ainda, que, tendo realizado seus estudos nos anos [de 19]30, o pesquisador teve de realizar seus esforçóes me meio à falta de estatísticas oficiais sobre a realidade dos grupos raça/ cor de nosso país, fato este que năo deve ser minimizado para um estudioso formado na tradiçáo sociológica norte-americana. Isto o obrigou a realizar levantamentos empíricos em relaçâo em diversos círculos sociais da cidade, tais como ocupaçôes profissionais, escolas, clubes, igrejas, sindicatos, nos jogos, etc., visando suprir àquela lacuna. Em suma, Brancos e pretos na Bahia representou um notável esforço de aplicaçăo empírica dos fundamentos teóricos da Escola de Chicago. Por este motivo, justificadamente, pode-se considerar esta obra enquanto um clássico do estudo das relaçōes raciais e da sociedade brasileira como um todo (PAIXÁO, 2014, p. 109). 
No entanto, apesar de todos os dados que Pierson recolheu, demonstrando que os negros, mesmo estando em todas as classes e ascendendo socialmente, ainda eram minoria nos estratos mais elevados, ele năo problematizou isso; também năo questionou o processo de miscigenaçâo e de branqueamento como forma de selecionar pessoas de pele mais clara nos espaços de poder ao mesmo tempo em que discriminava pessoas de pele mais escura, evidenciando as formas de tensâo racial. Ao explicar a ascensâo como resultado de talento e da capacidade do sujeito, o próprio autor desconsidera as condiçôes de discriminaçâo racial, culpabilizando próprio negro por seu insucesso e desconsiderando as novas dinâmicas do processo de integraçăo no mercado de trabalho, que nâo é fruto necessariamente do passado escravista (PAIXÂO, 2014).

$\mathrm{O}$ fato de destacar o talento pessoal do negro, que para Pierson foi visto como um fator positivo com relaçăo à mobilidade social, Paixâo (2014) aponta para uma formulaçâo especialmente cruel para a populaçáo negra, segundo o qual:

[...]podemos depreender dessaargumentaçăoqueosnegroseasnegrasqueremanescem nas piores posiçóes sociais ali estăo porque năo têm competência suficiente para sair dessa situaçăo infame, sendo assim os verdadeiros responsáveis por sua situaçáo de estrema penúria material [...] Caso a hipotética ausência de barreiras específicas à mobilidade social das pessoas dos distintos grupos de cor fosse real, por qual motivo, entăo, a prova de fogo do especial talento e capacidade teria de ser demonstrada exclusivamente pelos negros mestiços escuros? Por que para os brancos e mestiços claros tais critérios tornar-se-iam, em geral, desnecessários? Embora diferente da realidade norte-americana, tal configuraçáo náo estaria expressando a existência de assimetrias na distribuiçăo do prestígio social aos indivíduos segundo seus biótipos e a efetiva presença da discriminaçáo de raça/cor sobre o conjunto da populaçăo negra, especialmente no mercado de trabalho? (PAIXÂO, 2014, p. 112).

A citaçăo de Paixâo traz críticas à Pierson, uma delas a responsabilizaçăo do próprio negro por insucessos que sâo sociais e ao mesmo tempo exigir de pessoas negras maior esforço pessoas para superar dificuldades que nâo sâo obstáculos existentes para pessoas brancas, ou seja, para uns privilégios, para outros, desvantagens.

De acordo com Paixăo (2014), outro grupo de pesquisa das relaçóes étnico-raciais no Brasil que teve como referências os estudos da Escola de Chicago foi coordenado em conjunto por Charles Wagley, Thales de Azevedo e Luiz A. Costa Pinto. Sob orientaçâo de Wagley estiveram William Hutchinson, Marvin Harris e Benjamin Zimmerman, estes se dedicaram aos estudos de comunidades para compreender:

i)Alocalizaçáo ecológica daquelas quatro comunidades e suas respectivas composiçôes demográfica e racial; ii) $\mathrm{O}$ formato da estratificaçăo social daquelas comunidades; iii) Os sistemas de classificaçáo da cor das pessoas; iv) Os estereótipos sobre os negros; v) A relaçăo entre a cor dos indivíduos e as respectivas chances de mobilidade social; vi) Os conflitos sociais encontrados nas respectivas comunidades, e se os mesmos dialogavam com a cor das pessoas (PAIXĀO, 2014, p. 117).

As pesquisas acima mencionadas concluíram que as estruturas sociais e a mobilidade social quase sempre convergiam as linhas de cor e as de classe, onde a cor da pele era fator de impedimento prático para a ascensâo social, mesmo que legalmente todos pudessem ascender, pois na prática negros e mestiços escuros eram preteridos 
em situaçóes de competiçăo para oportunidades no mercado de trabalho, nas relaçóes inter-raciais, na educaçăo, provocando ofensas e desentendimentos (PAIXÂO, 2014).

Seguindo a base da Escola de Chicago e financiados pela Unesco tivemos ainda os estudos de Ruth Landes, Franklin Frazier e Melville Herskovits, estudiosos norte-americanos que focaram seus estudos na Bahia por considerarem esse local privilegiado devido a presença da populaçăo majoritariamente negra, atentando-se para a permanência e para a herança cultural africana. Suas pesquisas sobre a influência das religiōes de matriz afro-brasileiras, sobre o papel da mulher e da família negra evidenciam importantes (des) (re) construçóes das identidades negras no Brasil. Contudo, Paixăo (2014) questiona essa visâo ainda essencializada e estereotipada das pessoas negras e das culturas africanas e negras na diáspora:

De todo modo, compreendemos que as chances de uma abordagem essencialista da chamada cultura negra ficam menores quando os estudos logram incorporar nas correspondentes leituras elementos socioeconômicos e políticos; nesse último caso, incluindo os processos de lutas sociais existentes por parte dos grupos historicamente discriminados em prol do reconhecimento por parte do mundo dos brancos năo apenas de seus direitos sociais, mas, muitas vezes, mesmo, de sua elementar qualidade de seres humanos. Ou dito de forma sintética: no nosso entendimento, seja qual for a forma de sua manifestaçăo e grau de politizaçăo verbalizada, a cultura negra, tal como se desenvolveu nas Américas, é uma expressăo de resistência dos contingentes historicamente discriminados, descendentes dos antigos escravizados africanos, aos séculos marcados pela escravidăo, pela segregaçăo, pela discriminaçăo racial e pelo racismo (PAIXÂO, 2014, p. 164).

Algumas das lacunas percebidas pelos estudos sobre influência da Escola de Chicago no Brasil, serăo motivo de investigaçōes que tentam desmistificar a ideia de que no Brasil năo haveria preconceito de cor ou racial, e o esforço por destacá-las se faz necessário porque uma das atuais formas de suavizaçăo ou de desconsideraçâo da discriminaçấo ou desigualdade racial ainda se baseiam nos pressupostos de ser o Brasil um país miscigenado e que nâo vivenciou conflitos raciais, e, que, portanto, no Brasil tais problemas já teriam sido superados. Será mesmo?

\subsection{A Escola de Sociologia Paulista}

Veremos como as pesquisas de Fernandes (2007), Hofbauer (2006) e Pereira (2013) salientam as rupturas que Florestan Fernandes e Roger Bastide trarăo para pensar as relaçóes étnico-raciais, principalmente com a suposta harmonia racial defendida por Freyre (1977) e Donald Pierson (1971). Assim, esses autores também patrocinados pela UNESCO, dedicaram-se às pesquisas que ajudaram a desmistificar a noçăo paradisíaca das relaçôes étnico-raciais entre negros, índios e brancos no Brasil.

Em seu livro "O negro no mundo dos brancos", Florestan Fernandes (2007) vai contrapor Gilberto Freyre ao apresentar a ideologia da mestiçagem como uma característica que mantém a estrutura de desigualdade racial, sendo as marcas raciais uma espécie de indicativo da posiçâo social do negro, haja vista quanto mais escura a pele mais abaixo na escala social o indivíduo ficará. Nesse sentido, para Florestan 
Fernandes, tal realidade teria origem no passado escravista e a aboliçấo ocorreu sem reparaçâo social aos libertos nem a responsabilizaçăo dos senhores.

De acordo com Fernandes (2007) náo houve um preparo dessa força de trabalho para o ingresso no mundo industrial, por isso os negros entraram despreparados nesta competiçấo por postos de trabalho, onde os brancos imigrantes estariam em melhores condiçóes, motivo pelo qual as desigualdades raciais se mantiveram após a aboliçâo. Assim, o mesmo autor argumenta que essa condiçăo reforçava os estereótipos existentes contra as pessoas de cor, direcionados aos serviços mais pesados e com menor remuneraçâo, inclusive muitos, diante das dificuldades no mercado de trabalho, se envolveram com atividades ilícitas e com a criminalidade.

Na contramâo dessas afirmaçôes de F. Fernandes sobre o despreparo da máo-de-obra negra no pós-aboliçăo, nos baseamos em Domingues (2004) para fazer algumas ponderaçōes. Sobre a escassez de măo-de-obra especializada podemos apontar que já no século XIX, os homens livres eram maioria ao número de escravizados em Sáo Paulo, mesmo os escravizados já desenvolviam trabalhos especializados nos vários ofícios, conforme também Freyre (1977), além de que, em sua maioria, as atividades industriais náo dependiam de mâo-de-obra especializada, já que eram apreendidos no próprio oficio. Os jornais da época, dentre eles o Diário de Săo Paulo, também traziam registros que mostravam a habilitaçăo das pessoas negras nos anúncios de escravizados que fugiram, e outros como o Getulino, O Progresso e o Kosmos que denunciavam o preterimento de negros, que até se ofereciam às vagas, mas năo eram aceitos que participassem das seleçōes.

A partir de Domingues (2004, p. 98) podemos levantar mais um dado que descontrói a falaciosa inaptidâo do negro declarada por F. Fernandes, pois havia uma pequena burguesia negra que era formada por "libertos ou forros artesâos especializados e donos de oficinas, como: carpinteiros, alfaiates, ferreiros, ourives, barbeiros, dentistas, mineradores, mestres-de-obras, músicos, tropeiros, vendeiros e comerciantes de negócios diversos", mas que foram impedidos de desenvolver essas atividades e competências, pois à eles eram negados créditos bancários, o que hoje podemos apontar como uma das faces do racismo estrutural.

Em relaçăo a formaçăo escolar da populaçăo negra, Domingues (2004) traz dados do censo de 1920 que mostram como a alfabetizaçăo dos brasileiros era maior do que a dos imigrantes (80,3\% x 62,3\%), além dos estrangeiros se destacarem em quase o dobro dos analfabetos, evidenciando uma visăo fabricada pelas políticas de branqueamento do século XIX para substituir a máo-de-obra negra. Portanto, a năo absorçăo do negro como mâo-de-obra deveu-se à uma campanha ideológica e de discursos e legislaçôes oficiais explicada pelo racismo que impediu e eliminou as oportunidades de participaçăo do negro, sem se basear em critérios técnicos, mas sim raciais. Assim,

Florestan Fernandes comete o equívoco de analisar a situaçăo do negro isoladamente ou compará-la a de um imigrante idealizado. Como demonstramos, os imigrantes, na maioria, que entraram em Săo Paulo eram provenientes da zona rural, trabalhavam no campo e, por conseguinte, nâo tinham familiaridade com a indústria, tampouco com a ética do trabalho contratual. Neste caso, năo podemos partir do pressuposto de que os imigrantes previamente dominavam o "estilo urbano de vida" ou tinham um padrăo de comportamento regulado pelo "desenvolvimento da civilizaçăo urbana e industrial". 
"Ganhar a vida" conforme a "civilizaçăo urbana e industrial" năo foi algo inato do imigrante, mas resultado de um processo de adaptaçăo às novas oportunidades de emprego que foram negadas aos negros (DOMINGUES, 2004, p. 129).

Os dados apresentados por Domingues (2004) e sua crítica à F. Fernandes săo importantes para exercitar uma leitura mais aprofundada das relaçóes étnico-raciais no Brasil, no sentido de destacar que alguns pesquisadores clássicos cometeram equívocos indo mais além do que criticar pesquisador, a intençâo é evidenciar leituras enviesadas que permanecem no imaginário social e em pesquisas acadêmicas aligeiradas sobre o tema. E que enquanto pesquisadores estamos sujeitos a esses "erros", daí a importância de nâo olhar um autor ou uma questăo por um ângulo apenas.

Segundo Fernandes (2007) o padrăo de relaçôes raciais presente em Sáo Paulo nâo coadunavam com a propalada "democracia racial", pois os dados em que negros aparecem nos patamares mais baixos nos níveis de escolaridade e renda mostra que a "estrutura racial da sociedade brasileira, até agora, favorece o monopólio da riqueza, do prestígio e do poder pelos brancos. A supremacia branca é uma realidade no presente, quase tanto quanto foi no passado. A organizaçăo da sociedade impele o negro e o mulato para a pobreza, o desemprego ou o subdesemprego, e para o 'trabalho de negro'" (FERNANDES, 2007, p. 90).

Estas relaçôes seriam mantidas pela crença num mito de que aqui náo haveria discriminaçấo de cor, reforçando a ideia da miscigenaçâo como fator de integraçâo social e possibilidades de mobilidade social para pessoas de cor. Mas, Fernandes (2007) rebate tal mito ao destacar que o fato de existir estratificaçăo racial já era indicativo de desigualdade, além da mobilidade ser muito reduzida para pessoas negras, e quando estas ascendiam era esperado que um mestiço socializado e educado agisse como um branco, situaçăo bem conhecida na expressăo "negro de alma branca".

Por isso, à miscigenaçăo corresponderam mecanismos mais ou menos eficazes de absorçấo do mestiço. $\mathrm{O}$ essencial, no funcionamento desses mecanismos, năo era nem a ascensăo social de certa porçáo de negros e de mulatos nem a igualdade racial. Mas, ao contrário, a hegemonia da "raça dominante" - ou seja, a eficácia das técnicas de dominaçăo racial que mantinham o equilíbrio das relaçóes raciais e asseguravam a continuidade da ordem escravista. Os casos que afetavam a composiçăo das "grandes famílias" năo constituíam problema. Năo só eram pouco numerosos: as famílias possuíam recursos suficientes para educar os mestiços à imagem da figura do senhor. Por conseguinte, eles eram socializados para serem e agirem como "brancos", o que eles eram, de fato, social, jurídica e politicamente falando. $\mathrm{O}$ problema aparecia no outro nível: com os libertos, negros ou mestiços e com seus descendentes. No contexto da sociedade escravista, esses tipos humanos já apareciam associados a oportunidades sociais que equivaliam, formalmente, a uma mudança de status. Além disso, entregues a si mesmos, eles trabalhavam com frequência (a menos que fossem absorvidos pela economia de subsistência) pela conquista de posiçóes sociais mais altas, intensificando os estreitos mecanismos de mobilidade social vertical de que dispunha a sociedade escravista. A questăo consistia, literalmente, em obter a identificaçáo desses indivíduos aos interesses e valores sociais da "raça dominante". Como o controle do início e do fim de tais mecanismos se concentravam nas máos de representantes dessa "raça", tal como foi 
resolvido de forma pacífica e eficiente. Criou-se e difundiu-se a imagem do "negro de alma branca" - o protótipo do negro leal, devotado ao seu senhor, à sua família e à própria ordem social existente (FERNANDES, 2007, p. 44-45).

Para Fernandes (2007, p. 45), a "miscigenaçăo e a mobilidade social vertical operavam-se dentro dos limites e segundo as conveniências daquela ordem social", por isso as desigualdades raciais eram fruto de um passado escravista e de uma sociedade que ainda náo havia entrado de fato na fase de desenvolvimento capitalista, mas à medida que se modernizasse poderia aos poucos absorver a máo-de-obra de negros libertos e com isso permitir a sua integraçáo num sistema de classes e efetivando uma verdadeira democracia racial.

No entanto, de acordo com Paixăo (2014), essa perspectiva otimista de Florestan Fernandes para a integraçáo do negro na sociedade de classes já se mostrava falha na própria obra do autor, pois o recrutamento de negros para postos de trabalho eram impedidas com critérios de seleçâo que se pautavam na cor, além disso dentro do ambiente de trabalho haviam tratamentos preconceituosos por parte de imigrantes europeus com relaçấo aos seus colegas negros, por meio de brincadeiras, isolamentos e distanciamentos, bem como por comentários depreciativos, impedindo a sua plena integraçâo.

Conforme Paixăo (2014), Fernandes é um autor que destoa das análises precedentes sobre as relaçôes sociorraciais no Brasil, sem pretender naturalizar as assimetrias entre brancos e negros, pelo contrário, porém é preciso perceber que ao projetar a democracia racial como meta, acabou por ser um inspirador dessa matriz que negando as diferenças, acaba por reforçar as desigualdades raciais na medida em que năo as leva em consideraçăo na elaboraçăo das condiçôes de vida. Em segundo lugar "mesmo que à revelia da desejada intençâo de seus autores [...] caminha no mesmo sentido de ser uma elegante justificativa ideológica em prol da naturalizaçâo da convergência entre as linhas de classe e de cor da pele dentro de nossa pirâmide social" (PAIXĀO, 2014, p. 353).

Nesse sentido, Pereira (2013) apresenta Florestan Fernandes, e outros autores como Miriam Ferrara, Costa Pinto, por exemplo, estudiosos dos movimentos sociais numa mudança de perspectiva e uma sublimaçăo que, se por um lado deixou de racializar o negro, por outro năo deu devida importância as suas atuaçóes como agente dinâmico ${ }^{6}$, nem as suas contribuiçôes nas formulaçóes sobre as desigualdades marcadamente raciais.

Contudo, a reconhecida Escola de Sâo Paulo7 merece destaque, entre outros, por reforçar o termo "mito da democracia racial", como a desconstruçáo da ideia de

6 No texto "O negro e a luta de classes", de Clóvis Moura (1990), o termo "agente dinâmico" é utilizado para explicar as dinâmicas e interaçôes sociais, a capacidade de influenciar ou agir sobre mudanças sociais.

7 A escola de Sáo Paulo pode ser considerada como uma vertente dos estudos das relaçôes étnico-raciais no Brasil, com marcada influência da teoria marxista e as questōes de estratificaçāo social. De acordo com Hofbauer (2006, p. 278), os autores que "contribuíram para radicalizar e petrificar as concepçôes tipológicas no estudo das 'relaçōes raciais' foram Fernando Henrique Cardoso e Octávio Ianni", que reproduzem ideias de Fernandes, por isso acrescentamos o autor à referida escola, além de seu parceiro de pesquisas Roger Bastide, bem como Donald Pierson que em determinado momento de sua carreira desenvolveu pesquisas nessa linha em Sâo Paulo. 
paraíso racial existente no Brasil. Segundo Andrews (1998), as críticas feitas pelos pesquisadores da Unesco em relaçăo as desigualdades raciais já eram discutidas pelo Movimento Negro desde os anos 1930 pela Frente Negra Brasileira (FNB), que apesar de suas diversidades político-ideológicas, foi um dos primeiros movimentos negros organizados do Brasil no século XX a pautar ideias que seriam conhecidas pela luta de valorizaçăo da cultura e da identidade negra rebatendo a concepçăo de um país idílico entre seus grupos étnico-raciais.

Apesar da crítica fundamental ao "mito da democracia racial" efetivada na obra de F. Fernandes em contraponto a Freyre e a Pierson, seus leitores desatentos podem deixar de perceber certa nocividade ao desconsiderar a responsabilidade dos brancos com relaçăo aos crimes e discriminaçóes raciais cometidas contra pessoas negras, além de năo debater detalhadamente o efeito da "raça dominante" na estratificaçâo social e a reproduçâo de mecanismos que impedissem a mobilidade social ascendente dos negros e mestiços, muito menos considerou o impacto desse modelo e papel do branco na manutençáo das desigualdades raciais. Tal crítica pode ser encontrada em Bento (2014) que destaca a "omissâo ou abordagem simplista" das relaçôes raciais feitas por F. Fernandes ao atribuir uma "deformaçăo" somente às pessoas negras, ou o que a bibliografia traz como recorrente, o "problema do negro". Para Bento (2014):

[...] Florestan náo aborda a deformaçáo que a escravidăo provocou na personalidade do branco. Aliás, a decisáo de escravizar ou a omissăo frente ao sistema escravocrata já carrega em si indiscutíveis sinais de deformidade moral e ética. Como um estudioso de sua envergadura pôde deixar de analisar detidamente essa dimensăo tăo explícita do grupo branco, ao mesmo tempo em que conseguiu debruçar-se sobre a "deformidade" negra? [...] năo podemos chamar de omissăo o papel da elite branca de "virar as costas ao negro", tendo em vista que ela virou as costas sim, mas sem deixar de carregar consigo toda riqueza produzida em quase quatro séculos de trabalho escravo (BENTO, 2014, p. 51).

Para Bento (2014), quando F. Fernandes se refere ao branco como omisso nesse processo, ou quando o aborda como tendo melhor preparo para as condiçôes de trabalho emergentes, na verdade o que Fernandes reforça é um modelo de pensamento que trata o racismo como fato isolado e o branco como possuidor de qualidades superiores que o negro năo tinha, como organizaçăo para o trabalho e "atributos psicossociais de comportamento de um homem livre", como qualidades superiores (e inferiores) inatas, assim como desconsidera o teor e a envergadura da política de branqueamento do final século XIX pautado na racializaçăo definidor dessa lógica hierárquica.

Nessa perspectiva, o negro em ascensăo social buscaria um modelo de comportamento do branco, e esse processo seria um problema do indivíduo negro que tenta imitar os brancos e náo um problema estrutural do branqueamento, ou seja, é a culpabilização da vítima por um problema que náo é criado por ela, mesmo sendo vivido. Essa mesma estrutura racializada que permitiu a manipulaçâo de privilégios raciais para brancos ascenderem socialmente, evidenciando o branco, como aquele que age de modo sistematizado e, portanto, de modo bastante atuante na criaçăo e na manutençâo de posiçôes de vantagens/desvantagens raciais. 
Esse debate com a obra de F. Fernandes (2007) e seus críticos torna-se fundamental porque aponta a importância de se considerar a presença do branco para compreender as relaçóes étnico-raciais no Brasil, haja vista que náo podem ser compreendidas senáo nas dinâmicas das suas relaçóes.

Outro ponto que críticos de F. Fernandes (2007) apontaram foi olhar estas mesmas relaçôes por uma ótica, que como dissemos, retira e isenta a responsabilidade do branco enquanto portador de privilégios raciais, atribuindo, portanto, somente às pessoas negras, o ônus de um contexto marcado por relaçôes raciais assimétricas, desconsiderando o entendimento necessário do fenômeno para encontrar saídas para as desigualdades presentes, também, no espaço escolar.

\subsection{Novos estudos sobre as relaçóes étnico-raciais no Brasil}

Paixâo (2014) menciona que os estudos sobre relaçōes raciais no Brasil passaram por um "interregno", ou seja, fatores políticos como a Ditadura Militar e a especializaçấo no campo acadêmico voltada às questóes de classe e provocaram "certa aridez no meio acadêmico brasileiro" nos estudos das questóes raciais, e em que meados de 1970, tais questōes estavam "praticamente banidas".

Ainda assim, alguns pesquisadores nâo deixaram de se preocupar com este fator caro ao desenvolvimento da sociedade brasileira, e que trouxeram uma preocupaçáo já apontada por Bento (2014) nesse texto, como as críticas sobre o modo como até entăo se olhava para o negro como coisa, como "o problema do negro"; assim, mesmo durante certo ostracismo acadêmico sobre as relaçôes raciais podemos pensar que tiveram aqueles que se dedicaram a apresentar as pessoas negras como sujeitos, além de ressaltar as relaçôes étnico-raciais como análise destacando a participaçâo das pessoas brancas.

No entanto, esses estudos contemporâneos sobre as relaçōes étnico-raciais năo foram consensuais, havendo divergências, enquanto uns tentaram superar algumas lacunas como considerar a questăo racial como epifenômeno da questâo de classe, ou de apresentar uma visăo idílica sobre as relaçóes entre pessoas negras e brancas no Brasil, outros trouxeram a variável estrutural, e apesar de apresentarem a democracia racial como mito, ainda tinham uma visăo de relaçóes raciais como de segunda ordem, ou menos relevante que o fator social, como Fernandes (2007). Paixăo traz que:

Da literatura acadêmica produzida no Brasil nos anos 1970, dedicada ao tema das relaçōes raciais no período contemporâneo (aqui excluindo os estudos históricos sobre relaçôes raciais na sociedade escravista), sem a necessária pretensăo de esgotar a lista, podemos destacar os estudos de Amaury de Souza (Raça e política no Brasil urbano, 1971). Eduardo Oliveira (O mulato como obstáculo epistemológico, 1974), Tereza Costa (O princípio classificatório "cor", sua complexidade e implicaçóes para um estudo censitário, 1974); Clóvis Moura (O negro - de bom escravo a mau cidadâo, 1977), Lélia Gonzales (O papel da mulher negra na sociedade brasileira, 1979), além de algumas coletâneas publicadas no período por Thales de Azevedo (Democracia racial: ideologia e realidade, 1975) e Florestan Fernandes (Negro no mundo dos brancos, 1972, e Circuito fechado, 1976), muito embora, no 
caso destes dois últimos autores, a maior parte dos textos que fizeram parte desses livros tenha sido escrita ainda na década de 1960 (PAIXÂO, 2014, p. 369).

Segundo Paixăo (2014) apesar dessas contribuiçóes do Brasil, as que tiveram maior relevância foram as estrangeiras, mesmo que năo tenham sido necessariamente uma crítica à produçâo nacional, com destaque para Thomas Skidmore, Marvin Harris, Pierre van den Berghe, Carl Degler e Harold Hoetinik. Para ele, "[...] em quase todas aquelas abordagens [...] existiu uma convergência básica, no sentido de mostrar que no Brasil, o preconceito e a discriminaçấo contra negros era uma realidade, muito embora mitigados por fatores culturais que contrabalançavam tais atitudes" (PAIXĀO, 2014, p. 393).

Pereira (2013), traz Carlos Alfredo Hasenbalg como um dos que compóe os novos estudos das relaçóes raciais no Brasil, de modo radical à parte do pensamento social em vigência. Hasenbalg (2005) concorda que a ideia de "democracia racial" é um mito e vai além, pois realiza pesquisas quantitativas para demonstrar a materialidade das desigualdades raciais e que estas năo eram só frutos do passado escravista no Brasil, como pensava F. Fernandes, já que também prova a novas facetas das desigualdades raciais pós-aboliçâo e que existem desigualdades que independem da classe social, ou seja, mesmo que algumas pessoas negras ascendam socialmente podem continuar sofrendo discriminaçóes raciais, já que o racismo ocorre independente das questóes sociais ou de classe. Assim, para Hasenbalg (2005) a raça categoria considerada autônoma para explicaçăo de desigualdades, pois ela explica o racismo independente da classe:

Em suma, a raça como traço fenotípico historicamente elaborado, é um dos critérios mais relevantes que regulam os mecanismos de recrutamento para ocupar posiçóes na estrutura de classes e no sistema de estratificaçáo social. Apesar de suas diferentes formas (através do tempo e espaço), o racismo caracteriza todas as sociedades capitalistas multirraciais contemporâneas. Como ideologia e como conjunto de práticas cuja eficácia manifesta-se numa divisăo racial do trabalho, o racismo é mais do que um reflexo epifenomênico da estrutura econômica ou um instrumento conspiratório usado pelas classes dominantes para dividir os trabalhadores. Sua persistência histórica náo deveria ser explicada como mero legado do passado, mas como servindo aos complexos e diversificados interesses do grupo racialmente supraordenado no presente (HASENBALG, 2005, p. 124).

No pensamento de Hasenbalg (2005), a categoria raça se constitui como atributo socialmente elaborado funcionando como critério com eficácia própria dentro da estrutura de classes, pois é a base da dinâmica do racismo, entendido como um conjunto de práticas materiais e simbólicas de discriminaçăo racial disseminadas por meio das instituiçóes - com destaque para família e sistema escolar - que funcionam como aparatos ideológicos. De acordo com Hasenbalg (2005), estes săo responsáveis por produzir e distribuir características (simbólicas, materiais e psicológicas) pessoais como expectativa, habilidade técnica, personalidade, bem como as posiçôes de classe. Portanto, essa distribuiçăo vai posicionar sujeitos na estratificaçăo social e será traduzida em hierarquias raciais pelo mercado de trabalho, sendo a raça uma das características que interfere na distribuiçáo do poder. 
Nesse sentido, Hasenbalg, citado por Pereira (2013) esclarece a necessidade de perceber que a ideia de raça biológica náo pode ser reforçada, mas a ideia de raça como fenômeno social sim, pois o imaginário decorrente de uma ideia hierarquizada de raça vai produzir relaçóes e realidades sociais que perpetuam desigualdades com base na diferenciaçăo racial. Essa ideia foi e será compartilhada e construída em diálogo com o Movimento Negro que também vai buscar na negritude uma ideia de raça em comum para se referir as/aos negras/os na diáspora, de mesma ancestralidade e com vistas a superar o mesmo problema.

A distribuiçăo desses bens materiais e simbólicos săo acumulados de modo que podem se sobrepor e intensificar desigualdades também acumuladas ao longo da vida, desde os bens adquiridos na socializaçăo familiar, passando pelas várias etapas da vida de um sujeito, causando impactos nas etapas seguintes. Esse processo foi analisado por Hasenbalg e Silva, como explica Lima (2014) que:

Esse modelo de análise está ampliado no último livro publicado pelos autores, Origens e Destinos: Desigualdades Sociais ao Longo da Vida, no qual eles apontam diferentes etapas do ciclo de vida e identificam as dimensóes que devem ser observadas em cada uma delas. O ciclo inicia-se com a origem familiar - onde se observam a situaçấo social das famílias e os recursos disponíveis a seus membros, fundamentais para a trajetória socioeconômica dos indivíduos. $\mathrm{Na}$ fase seguinte considera-se a internalizaçâo de recursos, etapa em que devem ser observadas as condiçôes e possibilidades nas quais crianças e adolescentes dessas famílias iniciam sua trajetória social. A terceira e quarta fases correspondem à autonomizaçâo de status - momento em que o jovem começa a adquirir status social próprio, marcada pelo ingresso no mercado de trabalho - e a realizaçâo de status definida a partir da posiçăo dos indivíduos na estrutura sócio-ocupacional (sic) e da distribuiçăo da renda. Este ciclo gera determinadas condiçôes de renda familiar e pobreza que culminam no momento no qual voltamos ao estágio inicial do ciclo (Hasenbalg e Silva apud LIMA, 2014, p. 925).

A partir dessa análise, podemos perceber que as desigualdades raciais se retroalimentam, e se tratando das desigualdades raciais, estas também serăo vivenciadas acumuladamente, nas diversas etapas de vida, e acumuladamente nos vários espaços e situaçóes sociais, de modo que quando uma pessoa negra chega ao pleno desenvolvimento material e simbólico, diante de tantos obstáculos será exceçăo.

Percebemos entâo que existe simultaneamente aspectos econômicos e ideológicos, reforçando ou năo as características raciais, envolvidos na dinâmica de dominaçăo e reproduçăo de posiçôes materiais e simbólicas, dentro da estrutura de classes, que variam de acordo com: origem social, habilidade mental, educaçăo, ocupaçăo e renda, por exemplo, sendo que a mudança de posiçôes distributivas nâo significa mobilidade de classes, por sua vez a mobilidade de classe pode nâo alterar as dinâmicas raciais da distribuiçấo de poder e status.

$\mathrm{O}$ autor ressalta ainda que as desigualdades raciais tiveram suas expressóes no passado escravista, mas que năo serâo eliminadas com a industrializaçăo, como analisava F. Fernandes nos anos de 1950, porque as relaçôes na modernidade trouxeram novas formas de hierarquias baseadas na raça, mantidas e reproduzidas por instituiçôes sociais, bem como contesta o marxismo ortodoxo para o qual o preconceito 
racial seria estratégia para dividir os trabalhadores ao mostrar as cisóes que podem existir dentro das classes (HASENBALG, 2005).

Os estudos de Hasenbalg (2005) explicam que após a aboliçâo da escravatura, os negros ocuparam posiçōes na produçâo e distribuiçăo diferentes daquelas posiçôes dos brancos, porque foram introduzidos nas relaçóes de trabalho capitalista com desvantagens iniciais, cuja raça foi uma das razôes excludentes; a opressăo racial beneficiou as/os brancas/os. Segundo ele, brancos/as como um todo, pois os capitalistas exploram uma máo de obra mais barata que sâo os negros/as, bem como beneficia as/os brancas/os náo capitalistas porque ganham vantagem competitiva no preenchimento das posiçōes na estrutura de classes com recompensas materiais e simbólicas, por consequência com maiores chances de mobilidade social.

\section{CONCLUSÃO}

As matrizes teóricas de interpretaçâo das relaçōes étnico-raciais no Brasil apresentadas nos ajudam a compreender as relaçóes étnico-raciais enquanto resultado de processos complexos e apesar de distantes no tempo, ainda estáo presentes enquanto fenômenos sócio-históricos, os quais foram e săo alicerces para a construçăo de formas de ver e localizar as pessoas negras e brancas na estrutura social.

Muitas das ideias e teorias apresentadas hoje circulam socialmente como discursos para omitir conflitos sociais, mas também, como é nosso caso, destacar a questăo racial como central para entender tanto as desigualdades raciais como propostas de superaçấo. No que tange as questôes no contexto escolar, permite analisar em que medida a escola reproduz uma educaçăo eurocentrada em que os conflitos raciais, se năo forem silenciados, săo vistos só como o problema do negro. Ou também pode ajudar a desnaturalizar práticas e pensamentos em que pessoas negras sáo inferiorizadas por materiais didáticos e em relaçôes que tratam ofensas e xingamentos como brincadeiras.

A base teórica levantada nos permite perceber as relaçōes étnico-raciais enquanto permeadas por diferentes discursos e motivaçóes, presentes no contexto escolar, bem como fundamentar outras pesquisas que considerem as relaçóes étnico-raciais uma questăo ampla a ser debatida e enfrentada por pessoas brancas principalmente, historicamente menos visibilizadas por tais pesquisas.

As matrizes que trouxemos indicam que nâo há possibilidade de pensar tais questōes sem considerar todos os envolvidos, pessoas negras e brancas, justamente porque săo relaçóes que se constroem, reformulam e se transformam vinculadas uma a outra, mesmo que de forma ainda hierarquizada. 


\section{REFERÊNCIAS}

ANDREWS, George Reid. Negros e Brancos em Săo Paulo. Săo Paulo: EDUSC, 1998.

BENTO, Maria Aparecida Silva. Branqueamento e Branquitude no Brasil. In: CARONE, Iray. BENTO, Maria Aparecida Silva (Orgs.). Psicologia social do racismo: estudos sobre branquitude e branqueamento no Brasil. 6. ed. - Petrópolis, RJ: Vozes, 2014. p. 25-57.

BETHENCOURT. Francisco. Racismos: das Cruzadas ao século XX. Săo Paulo: Companhia das Letras, 2018.

COSTA, Sérgio. Dois atlânticos: teoria social, anti-racismo, cosmopolitismo. Belo Horizonte: Editora UFMG, 2006.

DOMINGUES, Petrônio. Uma história náo contada: negro, racismo, e branqueamento em Săo Paulo no pós-aboliçáo. Sáo Paulo: Editora Senac, 2004.

FERNANDES, Florestan. 0 negro no mundo dos brancos. 2 ed. Revista. Săo Paulo: Global, 2007.

FREYRE, Gilberto. Casa-grande \& senzala: formaçăo da família brasileira sob o regime da economia patriarcal. 18 ed. Rio de Janeiro: José Olympio, 1977.

GUIMARĀES. Antônio Sérgio. Como trabalhar com "raça" em sociologia. Revista Educaçăo e Pesquisa, Săo Paulo, v.29, n.1, p. 93-107, jan./jun. 2003.

HASENBALG, Carlos. Discriminaçăo e desigualdades raciais no Brasil. Săo Paulo: Ed. Humanitas, 2005.

HOFBAUER, Andreas. Uma história do branqueamento ou o negro em questăo. Sáo Paulo: Unesp, 2006.

LEITE, Dante Moreira. 0 caráter nacional brasileiro: história de uma ideologia. 7 ed. Ver. Săo Paulo: Editora Unesp, 2007.

MOURA, Clóvis. As injustiças de Clio: o negro na historiografia brasileira. Belo Horizonte: Oficina de Livros, 1990.

NOGUEIRA, Oracy. Tanto preto quanto branco: estudo de relaçóes raciais. Săo Paulo: T.A. Queiroz, 1985.

PAIXÂO, Marcelo. A lenda da modernidade encantada: por uma crítica ao pensamento social brasileiro sobre relaçôes raciais e projeto de Estado-Naçăo. - 1.ed. - Curitiba, PR: CRV, 2014.

PEREIRA, Amauri Mendes. Para além do racismo e antirracismo: a produçâo de uma cultura de consciência negra na sociedade brasileira. Itajaí: Casa Aberta Editora, 2013.

PIERSON, Donald. Brancos e prêtos na Bahia: estudo de contacto racial. $2^{a}$ ed. Sáo Paulo: Editora Nacional, 1971.

RAMOS, Alberto Guerreiro. Patologia social do "branco" brasileiro. In: crítica a Sociologia Brasileira. Rio de Janeiro: Andes, 1957. p. 171-202. . A introduçáo SCHWARCZ, Lilia Moritz. 0 espetáculo das raças: cientistas, instituiçóes e questăo racial no Brasil - 1870-1930. Sáo Paulo: Companhia das Letras, 1993. 
SEYFERTH, Giralda. As ciências sociais no Brasil e a questăo racial". In: WANDERLEY, Regina. Cativeiro \& Liberdade. Rio de Janeiro: UERJ, 1989. p. 11-31.

SKIDMORE, Thomas. Preto no branco: raça e nacionalidade no pensamento brasileiro. Rio de Janeiro: Paz e Terra, 1976. 